\title{
The analysis of the potential for the use of gaseous fuels in the municipal bus transport in Poland - part 1
}

\begin{abstract}
The paper discusses issues related to the use of compressed natural gas $(C N G)$ in combustion engines particularly in municipal bus transport. The ecological aspects of the use of natural gas in road transport have been analyzed particularly the exhaust emissions in comparison to the emissions from diesel engines. Advantages and disadvantages of natural gas fueling as well as the current level of CNG use in transport have been presented both in Poland and worldwide. The authors have also indicated the motivating arguments for the use of natural gas.
\end{abstract}

Key words: combustion engines, natural gas, bus transport, city buses

\section{Analiza możliwości zastosowania gazowych paliw w miejskim transporcie autobusowym w Polsce - część 1}

\begin{abstract}
W artykule omówiono problematykę wykorzystywania sprężonego gazu ziemnego (CNG) przez silniki spalinowe, przede wszystkim w obszarze miejskiej komunikacji autobusowej. Scharakteryzowano aspekty ekologiczne stosowania gazu ziemnego w transporcie samochodowym, szczególnie w porównaniu z poziomem emisji substancji toksycznych silników ZS. Przedstawiono wady i zalety napędu gazowego, obecny poziom wykorzystania CNG w transporcie zarówno w Polsce, jak i na świecie oraz argumenty motywujące do jego wykorzystania.
\end{abstract}

Słowa kluczowe: silniki spalinowe, gaz ziemny, transport autobusowy, autobusy miejskie

\section{Introduction}

Natural gas is one of the fuels used is transport and is quite common in many countries of the world, South America and Asia in particular.

A natural substitute for natural gas used in transport is biogas i.e. biomethane originating from renewable energy sources. Such sources use agricultural and municipal biogas generating facilities based on municipal waste and sewage.

In Scandinavia and Germany biomethane has recently been introduced as a vehicle fuel for city transit buses in particular.

The idea of the use of gaseous fuels (natural gas mainly) in road transport including municipal transport has been known and implemented in Poland as well. It has great potential for development particularly in the municipal transit sector, also in the aspect of the works carried out on the introduction of biomethane manufactured from waste as energy carrier [1].

\section{Natural gas as a vehicle fuel worldwide}

Approximately 10 million vehicles are used worldwide that are powered with natural gas (NGV - Natural Gas Vehicles), which constitutes approximately $1.2 \%$ of the worldwide vehicle fleet. The number of NGV buses in the world amounts to almost 270 thousand units (Table 1).

The largest number of NGV vehicles was registered in 2009 in Pakistan (more than 2.1 million), Argentina (almost 1.8 million), Brazil (approximately 1.6 million) and Iran (more than 1.5 million).

Among the European countries Italy takes the dominating position where almost 590 thousand NGV vehicles are regis-

\section{Wprowadzenie}

Gaz ziemny jest obecnie paliwem wykorzystywanym w transporcie i rozpowszechnionym w wielu krajach świata, szczególnie w krajach Ameryki Południowej i Azji.

Zamiennikiem wykorzystywanego w transporcie gazu ziemnego może być biogaz, a ściślej biometan pochodzący z odnawialnych źródeł energii. Takie źródła wykorzystują biogazownie rolnicze i biogazownie komunalne bazujące na surowcach, jakimi są odpady komunalne i ścieki komunalne.

W krajach skandynawskich, a także w Niemczech biometan wykorzystywany jest od niedawna do zasilania silników samochodowych, przede wszystkim do zasilania silników autobusów miejskich.

Idea wykorzystywania paliwa gazowego (głównie gazu ziemnego) w transporcie samochodowym, w tym w miejskim transporcie autobusowym jest znana i także wdrażana w Polsce. Ma ona duże szanse rozwoju, szczególnie właśnie w sektorze miejskich przewozów autobusowych, także w kontekście prac nad wdrożeniem w kraju jako nośnika energii biometanu produkowanego z surowców odpadowych [1].

\section{Gaz ziemny jako paliwo silnikowe na świecie}

$\mathrm{Na}$ świecie eksploatowanych jest około $10 \mathrm{mln}$ pojazdów zasilanych gazem ziemnym (NGV - Natural Gas Vehicles), co stanowi około 1,2\% parku samochodowego. Liczba autobusów NGV na świecie wynosi prawie 270 tys. sztuk (tab. 1).

Najwięcej samochodów NGV zarejestrowanych było w 2009 r. w Pakistanie (przeszło 2,1 mln), Argentynie (blisko 1,8 $\mathrm{mln}$ ), Brazylii (około 1,6 mln) i Iranie (ponad 1,5 mln). 
tered. Germany registered approximately 84 thousand NGVs and Bulgaria more than 60 thousand. In Poland in 2009 the number of NGV vehicles amounted to 1.8 thousand.

As at the end of 2008 the largest number of NGV buses (approximately 113 thousand) was registered in China. Columbia operates approximately 14 thousand units, India approximately 12 thousand and Armenia - 10 thousand.

Among the European countries the largest number of NGV buses is operated in Italy - approximately 2.3 thousand, next comes France - approximately 2.1 thousand, Germany - 1.5 thousand. In Poland as at the end of 2009 the total number of registered NGV buses was 300 .

In many countries a variety of financial incentives have been introduced that aimed at stimulating the investment in CNG (Compressed Natural Gas) vehicles.

In the United States of America the incentive for purchasing of $\mathrm{CNG}$ vehicles was the introduction of tax relieves i.e.
W Europie dominują Włochy, w których zarejestrowano prawie 590 tys. samochodów NGV. W Niemczech zarejestrowanych było około 84 tys., a w Bułgarii przeszło 60 tys. samochodów NGV. W Polsce, w 2009 r., liczba takich samochodów wyniosła 1,8 tys.

Autobusów NGV najwięcej (bo około 113 tys.) zarejestrowanych było w końcu 2008 r. w Chinach. W Kolumbii eksploatowano ich około 14 tys., w Indiach około 12 tys., w Armenii około 10 tys.

Wśród krajów europejskich najwięcej autobusów NGV eksploatuje się we Włoszech - około 2,3 tys., następnie we Francji - około 2,1 tys., w Niemczech 1,5 tys. W Polsce w końcu 2009 r. łącznie zarejestrowanych było 300 autobusów NGV.

W wielu krajach wdrożono różnego typu zachęty finansowe stymulujące inwestowanie w pojazdy zasilane sprężonym gazem ziemnym (CNG - Compressed Natural Gas).

Table 1. Global motor vehicle fleet, including vehicles fueled with compressed natural gas [5] Tabela 1. Światowy park pojazdów samochodowych, w tym pojazdów zasilanych sprężonym gazem ziemnym [5]

\begin{tabular}{|c|c|c|c|c|c|c|c|c|}
\hline \multirow[t]{2}{*}{ Country/kraj } & \multicolumn{4}{|c|}{ Vehicle fleet/park pojazdów samochodowych } & \multicolumn{4}{|c|}{$\begin{array}{l}\text { Vehicle fleet fitted with CNG engines/park pojazdów samocho- } \\
\qquad \text { dowych zasilanych CNG }\end{array}$} \\
\hline & $\begin{array}{l}\text { Total/ } \\
\text { ogółem }\end{array}$ & $\begin{array}{l}\text { Passenger and light } \\
\text { duty trucks/samo- } \\
\text { chody osobowe } \\
\text { i dostawcze }\end{array}$ & $\begin{array}{l}\text { Buses/ } \\
\text { autobusy }\end{array}$ & $\begin{array}{l}\text { Heavy duty } \\
\text { trucks/ } \\
\text { samochody } \\
\text { ciężarowe }\end{array}$ & $\begin{array}{l}\text { Total/ } \\
\text { ogótem }\end{array}$ & $\begin{array}{l}\text { Passenger vehicles } \\
\text { and light duty trucks/ } \\
\text { samochody osobowe } \\
\text { i dostawcze }\end{array}$ & $\begin{array}{l}\text { Buses/ } \\
\text { autobusy }\end{array}$ & $\begin{array}{l}\text { Heavy duty } \\
\text { trucks/ } \\
\text { samochody } \\
\text { ciężarowe }\end{array}$ \\
\hline Argentina & 7.608 .744 & & & & 1.763 .751 & 1.763 .751 & 0 & 0 \\
\hline Armenia & 327.477 & & & & 99.428 & 69.971 & 9.831 & 19.626 \\
\hline Bangladesh & 293.472 & & & & 128.817 & 117.229 & 3.233 & 8.355 \\
\hline Bolivia & 475.632 & & & & 99.657 & 99.657 & 0 & 0 \\
\hline Brazil & 35.120 .203 & 32.976 .848 & 357.984 & 1.785 .371 & 1.596 .511 & 1.596 .511 & 0 & 0 \\
\hline Bulgaria & 2.733 .000 & 2.500 .000 & 23.000 & 210.000 & 60.236 & 60.000 & 216 & 20 \\
\hline China & 35.860 .638 & & & & 345.540 & 231.685 & 112.755 & 1.100 \\
\hline Columbia & 1.238 .216 & & & & 291.360 & 267.900 & 13.800 & 9.660 \\
\hline Egypt & 2.373 .723 & & & & 109.359 & 107.442 & 1.209 & 708 \\
\hline Germany & 44.020 .615 & 43.044 .875 & 75.068 & 900.672 & 83.747 & 78.610 & 1.513 & 3.624 \\
\hline India & 14.554 .000 & & & & 327.915 & 315.200 & 12.000 & 715 \\
\hline Iran & 11.193 .992 & 10.477 .245 & 211.571 & 505.176 & 1.537 .790 & 1.532 .268 & 5.522 & 0 \\
\hline Italy & 40.368 .067 & 39.267 .649 & 96.419 & 1.003 .999 & 588.077 & 584.577 & 2.300 & 1.200 \\
\hline Pakistan & 2.724 .000 & 2.441 .000 & 110.000 & 173.000 & 2.141 .000 & 2.140 .960 & 40 & 0 \\
\hline Peru & 1.195 .348 & & & & 66.124 & 66.113 & 11 & 0 \\
\hline Poland & 17.196 .873 & 16.413 .389 & 87.586 & 695.898 & 1.806 & 1.502 & 300 & 4 \\
\hline Russia & 35.455 .227 & 29.404 .921 & 882.457 & 5.167 .849 & 61.000 & 18.000 & 8.000 & 35.000 \\
\hline Thailand & 24.916 .525 & 24.073 .830 & 116.054 & 726.641 & 145.592 & 119.888 & 10.195 & 15.509 \\
\hline Ukraine & 4.949 .346 & & & & 67.000 & 7.000 & 30.500 & 29.500 \\
\hline USA & 241.212 .763 & 231.905 .000 & 807.053 & 8.500 .710 & 100.000 & 86.500 & 11.000 & 2.500 \\
\hline $\begin{array}{l}\text { Other coun- } \\
\text { tries }\end{array}$ & 350.536 .381 & & & & 289.512 & 217.532 & 47.301 & 24.679 \\
\hline $\begin{array}{l}\text { Countries } \\
\text { where NGV } \\
\text { are widely } \\
\text { used }\end{array}$ & 874.354 .242 & & & & 9.904 .222 & 9.482 .296 & 269.726 & 152.200 \\
\hline $\begin{array}{l}\text { Other coun- } \\
\text { tries }\end{array}$ & 5.144 .775 & & & & 0 & 0 & 0 & 0 \\
\hline Total World & 879.499 .017 & & & & 9.904 .222 & 9.482 .296 & 269.726 & 152.200 \\
\hline
\end{tabular}


Expressway tax has been reduced for vehicles fueled with CNG and LNG (Liquefied Natural Gas), $80 \%$ of the difference in the purchasing cost of a CNG/LNG fueled engine was subsidized as compared to the cost of a conventional engine (that included relevant modification of conventional engines). Besides, tax relieves were introduced for the investors in the CNG stations (up to USD 100 thousand) [12].

In Germany the $\mathrm{CNG}$ incentive program consists in direct subsidies for vehicles that are to be converted to CNG fueling or new vehicles already $\mathrm{CNG}$ compliant. The government has determined in advance (for the 10 year period) the level of tax imposed on the CNG fuel (it is more advantageous in comparison to other fuels). Individual owners take advantage of the reduced tax rate for this type of vehicles, hence they can buy the fuel at better prices. An significant extension of the CNG fueling network is underway in collaboration with gas companies that distribute this fuel.

In France the gas companies actively participate and help in preparation of the CNG projects and securing necessary financing for them. The government forced the city councils (cities of population exceeding 200 thousand) to purchase $50 \%$ of new buses fueled with ecological fuels. Currently approximately $1 / 3$ of the purchased fleet is CNG vehicles. In 35 French cities every third new bus is fueled with $\mathrm{CNG}$.

According to the ENGVA forecast in 2020 in the area of Europe there may be even up to 70 thousand intercity buses, approximately 23 thousand city buses, approximately 150 thousand heavy duty trucks, 450 thousand taxicabs, 7.6 million light duty trucks and over 15 million passenger cars fueled with natural gas [13].

\section{The conditions for development of the use of natural gas in transport}

Currently, almost every recognized vehicle manufacturer produces vehicles fitted with CNG engines. This confirms the fact that the companies treat the future challenge seriously and the economical analyses push them to invest in the CNG technology.

The fiscal policies in many countries are at the same time very convenient for the start-up phase of the CNG technology. The CNG pricing policy assumes that it should be competitive to the prices of diesel oil. The price of natural gas will most probably grow but at a much lower rate than the prices of other fuels.

The cost of erecting fueling stations is also high, but natural gas is not only an ecological fuel but also a safe fuel. Natural gas is lighter than air and in case of emergency it evaporates quickly. The only problem is to overcome the psychological barrier of associating the explosive nature of gas with unconditional danger. Convincing the users that at current technology advancement natural gas is truly safe despite high pressures and natural explosiveness is one of the tasks of the advocates of this energy carrier.

\section{The ecological aspects of the use of natural gas in transport}

Vehicles fitted with combustion engines are one of the key polluters of the environment. In city agglomerations the
W Stanach Zjednoczonych jako zachętę do kupna samochodów zasilanych gazem ziemnym wprowadzono wiele ulg podatkowych, m.in. obniżono podatek ,autostradowy” dla samochodów zasilanych CNG i LNG (Liquefied Natural Gas), wprowadzono zwrot $80 \%$ różnicy kosztów zakupu pojazdu z silnikiem gazowym w porównaniu do kosztów zakupu (lub przeróbki) pojazdu z silnikiem o zapłonie iskrowym lub samoczynnym. Ponadto wprowadzono ulgi podatkowe dla inwestujących w stacje tankowania gazu ziemnego (do 100 tys. dolarów) [12].

W Niemczech program wspierania wdrażanie CNG polega na dotacjach bezpośrednich do pojazdów przerobionych na zasilanie CNG lub nowo zakupionych przystosowanych fabrycznie do CNG. Państwo określiło z góry na 10 lat poziom podatków obciążających CNG (jest korzystniejszy w porównaniu z innymi paliwami). Indywidualni nabywcy korzystają z obniżonego podatku na ten rodzaj pojazdów, dzięki temu mogą kupować je taniej. Trwa intensywna rozbudowa sieci stacji napełniania $\mathrm{CNG}$ z udziałem firm gazowniczych dystrybuujących paliwo.

We Francji firmy gazownicze aktywnie uczestniczą i pomagają w przygotowaniu projektów CNG i zdobyciu środków finansowych na ten cel. Rząd zobowiązał samorządy miast o liczbie ponad 200 tysięcy mieszkańców do zakupu 50\% nowych autobusów na paliwo ekologiczne. Obecnie około 1/3 nowo kupowanych autobusów to pojazdy na CNG. W 35 miastach Francji co trzeci nowy autobus zasilany jest $\mathrm{CNG}$.

Według prognozy ENGVA w 2020 r. na obszarze Europy eksploatowanych może być prawie 70 tys. autobusów regionalnych, około 23 tys. autobusów miejskich, około 150 tys. samochodów ciężarowych, 450 tys. taksówek, 7,6 mln samochodów dostawczych i ponad $15 \mathrm{mln}$ samochodów osobowych napędzanych gazem ziemnym [13].

\section{Uwarunkowania rozwoju wykorzystania gazu ziemnego $\mathrm{w}$ transporcie}

Aktualnie prawie wszyscy znani producenci samochodów na całym świecie produkują modele pojazdów wyposażonych w silniki zasilane gazem ziemnym. Świadczy to o tym, że firmy poważnie traktują wyzwanie przyszłości, a analizy ekonomiczne nakazują im inwestowanie także w produkcję pojazdów zasilanych CNG.

Polityka podatkowa wielu państw jest jednocześnie bardzo dogodna dla fazy ,rozruchu” gazu ziemnego. Jeżeli chodzi o cenę paliwa w postaci gazu ziemnego to przyjmuje się, że powinna być ona konkurencyjna w stosunku do ceny oleju napędowego. Cena gazu prawdopodobnie będzie rosła, ale zapewne znacznie wolniej niż ceny innych paliw.

Wysoki jest też koszt budowy stacji tankowania, ale gaz ziemny jest nie tylko paliwem ekologicznym, lecz także paliwem bezpiecznym. Gaz ziemny jest lżejszy od powietrza, w razie awarii łatwo się ulatnia, nie stwarzając zagrożenia. Problemem jest pokonanie bariery psychologicznej polegającej na kojarzeniu zwiększonego zagrożenia z właściwością wybuchową gazu. Przekonanie użytkowników, że przy obecnej technice gaz ziemny jest naprawdę bezpieczny, 
traffic is responsible for generating $99 \%$ of carbon monoxide, $96 \%$ soot, $76 \%$ nitric oxides and is the main source of other toxic components such as benzene, sulfur dioxide and carbon dioxide.

Independent analyses have shown that natural gas already today helps the engines in meeting the world exhaust emission requirements.

Natural gas is mostly composed of methane (up to $98 \%$ ), which makes it an ecological fuel. In a single energy unit natural gas contains less carbon compounds than any other fossil fuel. The total exhaust emission emitted from engines fueled with natural gas are lower than those emitted by diesel engines.

One of the most successful ways to reduce the exhaust emissions containing compounds dangerous to human health is the use of gaseous fuels such as CNG. The application of biomethane for this purpose is an even better solution.

Natural gas, similarly to biomethane, can be used to fuel vehicles in the following forms $[5,6]$ :

- compressed to a pressure slightly above the ambient pressure - this solution is not currently applied particularly due to the little energy density of the fuel,

- compressed to the pressure of approximately (20-25) $\mathrm{MPa}$ stored in ambient temperature - CNG,

- liquefied, stored in the temperature of approximately $-163^{\circ} \mathrm{C}$ in ambient pressure - LNG.

The technique of the use of liquefied natural gas and biomethane for engine fueling is not yet very common (the technology is very promising though) but the use of compressed natural gas or biomethane $(\mathrm{CBG}-$ Compressed BioGas) is gaining in popularity.

CNG and biomethane can be used for fueling of the following type of combustion engines [6]:

- spark ignition engines:

- dual fuel engines - liquid fuel (gasoline) and gaseous fuel

- the engine can operate on gasoline or natural gas (during startup and idle gasoline only) - engines designed for gaseous fuels,

- diesel engines:

- dual fuel engines: liquid fuel (diesel oil) and gaseous fuel with the use of an ignition dose of diesel oil,

- engines using gaseous fuels with the ignition dose of diesel oil.

The most common solution in large engines is fueling spark ignition engines (converted from diesel engines) with $\mathrm{CNG}$ or biomethane (CBG). The most important design modifications of a diesel engine turned into a spark ignition engine fueled with CNG or CBG are the use of a spark plug instead of an injector, fitting the engine with an ignition system, reduction of the compression ratio, application of a throttle in the intake system, application of special controllers of the spark ignition processes that control the fuel dose or the ignition angle and fitting of a catalytic converter in the exhaust system [6].

There are two possibilities of application of the algorithms controlling the mixture compositions for gaseous fuels: mixture control to obtain stoichiometric mixture (in the mimo dużego ciśnienia oraz naturalnych właściwości wybuchowych - jest jednym z zadań dla popularyzatorów tego nośnika energii.

\section{Aspekt ekologiczny wykorzystywania gazu ziemnego $w$ transporcie}

Pojazdy z silnikami spalinowymi są jednym z największych emitentów zanieczyszczeń. W aglomeracjach miejskich ruch uliczny odpowiedzialny jest za generowanie 99\% tlenku węgla, 96\% sadzy, 76\% tlenków azotu i stanowi główne źródło innych niebezpiecznych związków, takich jak benzen, dwutlenek siarki i dwutlenek węgla.

Niezależne analizy wykazały, że gaz ziemny już dziś umożliwia spełnienie przez silniki obowiązujących światowych norm emisji substancji toksycznych z silników.

Gaz ziemny składa się w większości z metanu (nawet do $98 \%$ ), co powoduje, że jest paliwem ekologicznym. W przeliczeniu na jednostkę energetyczną gaz ziemny zawiera mniej związków węgla niż jakiekolwiek paliwo kopalne. Suma zanieczyszczeń emitowanych przez silniki zasilane sprężonym gazem ziemnym jest niższa $\mathrm{w}$ porównaniu $\mathrm{Z}$ silnikami ZS.

Jedną ze skutecznych metod zmniejszenia emisji substancji szkodliwych dla zdrowia ludzi i ich środowiska jest zastosowanie do zasilania silników spalinowych właśnie paliw gazowych, w tym CNG. Zastosowanie do tego celu biometanu jest jeszcze lepszym rozwiązaniem.

Gaz ziemny, podobnie jak biometan, może być wykorzystany do zasilania silników spalinowych w postaciach $[5,6]$ :

- sprężonej do ciśnienia nieznacznie większego od ciśnienia atmosferycznego - ten sposób nie znajduje obecnie zastosowania, przede wszystkim z powodu małej gęstości energetycznej przechowywanego paliwa,

- sprężonej do ciśnienia około (20-25) MPa, przechowywany w temperaturze otoczenia - $\mathrm{CNG}$,

- skroplonej, przechowywany w temperaturze około $-163{ }^{\circ} \mathrm{C}$, bez stosowania nadciśnienia - LNG.

Technika zastosowania skroplonego gazu ziemnego, podobnie jak biometanu, do zasilania silników spalinowych nie jest dotychczas jeszcze bardzo rozpowszechniona (choć wiąże się z nią duże nadzieje), natomiast zastosowanie sprężonego gazu ziemnego czy biometanu (CBG - Compressed BioGas) jest coraz bardziej popularne.

CNG i biometan mogą być stosowane do zasilania silników spalinowych w następujących rozwiązaniach konstrukcyjnych [6]:

- do zasilania silników o zapłonie iskrowym:

- dwupaliwowych, na paliwo ciekłe (benzynę) i gazowe - silnik może pracować na benzynie lub na gazie, z tym że na benzynie w fazie rozruchu silnika i zazwyczaj na biegu jałowym,

- zasilanych wyłącznie gazem,

- do zasilania silników o zapłonie samoczynnym:

- dwupaliwowych, na paliwo ciekłe (olej napędowy) lub gaz z zastosowaniem dawki zapłonowej oleju napędowego, 
basic field of work) using multifunction catalytic converter, mixture control to obtain lean mixture in the field of work at part loads. The most frequently used solution in engines used in city buses is the utilization of the mixture control algorithm to obtain a stoichiometric mixture [6].

The experience to date confirms numerous ecological advantages of the spark ignition engines fueled with

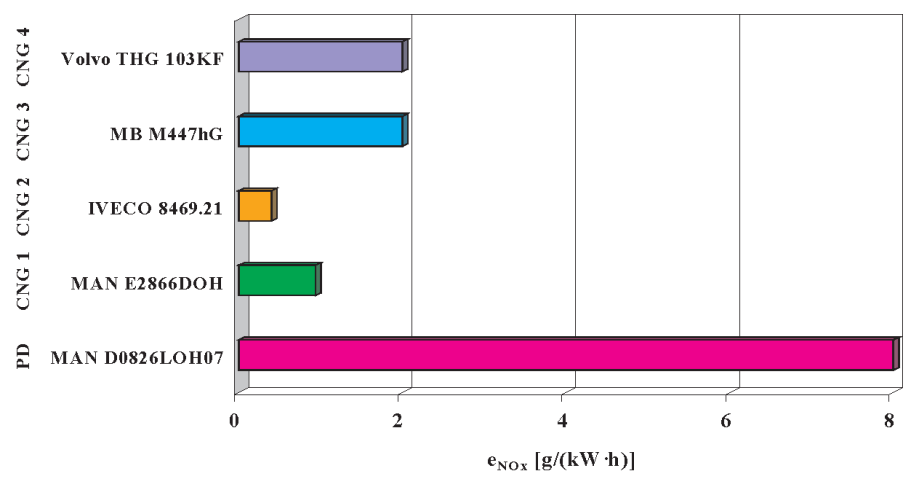

Fig. 1. Unit emission of nitrogen oxides in the dynamic ETC test Rys. 1. Emisja jednostkowa tlenków azotu w teście dynamicznym ETC

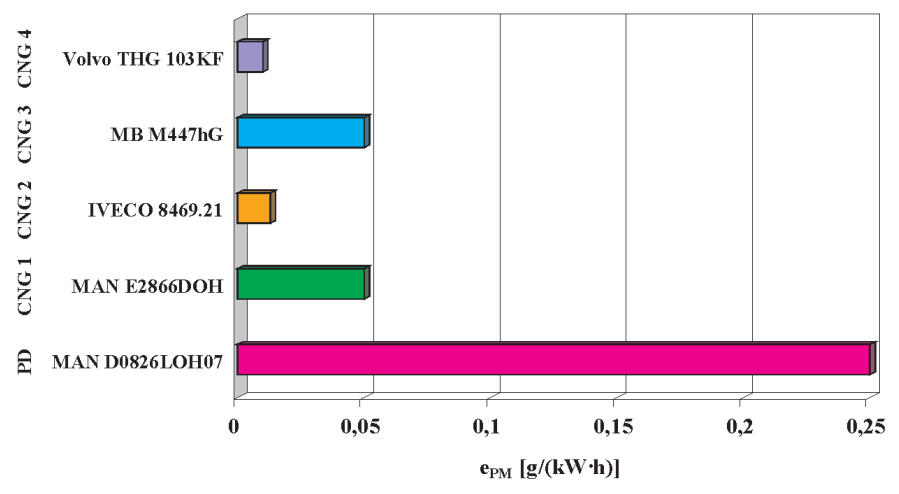

Fig. 2. Unit emission of particulates in the dynamic ETC test Rys. 2. Emisja jednostkowa cząstek stałych $w$ teście dynamicznym ETC
- jednopaliwowych na gaz z zastosowaniem dawki zapłonowej oleju napędowego.

Najczęściej występującym rozwiązaniem w dużych silnikach jest zastosowanie zasilania CNG lub biometanem (CBG) silników o zapłonie iskrowym, będących modyfikacją oryginalnych silników o zapłonie samoczynnym. Najważniejszymi zmianami konstrukcyjnymi silnika o zapłonie samoczynnym na silnik o zapłonie iskrowym, zasilany CNG lub CBG, jest: zastosowanie świecy zapłonowej w miejsce wtryskiwacza, wyposażenie silnika w układ zapłonu, konstrukcyjne zmniejszenie stopnia sprężania, zastosowanie przepustnicy w układzie dolotowym, zastosowanie specjalnych sterowników procesów roboczych w silniku, przede wszystkim dawki paliwa i kąta wyprzedzenia zapłonu, oraz zastosowanie w układzie wylotowym specjalnego reaktora katalitycznego [6].

Istnieją dwie możliwości zastosowania algorytmów sterowania składu mieszanki palnej silników o zapłonie iskrowym na paliwo gazowe: na mieszankę stechiometryczną (w podstawowym obszarze pracy) z wykorzystaniem wielofunkcyjnego reaktora katalitycznego oraz na mieszanki ubogie w obszarach pracy silnika na obciążeniach częściowych. Częściej stosowanym rozwiązaniem jest wykorzystanie sterowania składu mieszanki palnej na stechiometryczną [6].

Dotychczasowe doświadczenia potwierdzają liczne zalety ekologiczne silników o zapłonie iskrowym zasilanych sprężonym gazem ziemnym lub biometanem w stosunku do silników o zapłonie samoczynnym, przede wszystkim [6]:

- zmniejszenie emisji tlenku węgla,

- zmniejszenie emisji węglowodorów,

- znaczne zmniejszenie emisji węglowodorów pierścieniowych i ich pochodnych, w szczególności wielopierścieniowych węglowodorów aromatycznych,

- zmniejszenie emisji tlenków azotu,

- znaczne zmniejszenie emisji cząstek stałych.

Literatura dostarcza licznych informacji na temat wyników badań silników spalinowych zasilanych paliwami gazowymi, w szczególności ekologicznych skutków zastosowania gazu ziemnego do zasilania silników [6]. Informacje te są jednak w znacznym stopniu niejednolite, a niekiedy nawet sprzeczne. Dotyczy to szczególnie emisji zanieczyszczeń, bardzo uzależnionej od właściwości konstrukcyjnych silników oraz warunków ich pracy. Najwięcej informacji na temat emisji zanieczyszczeń z silników spalinowych, zasilanych gazem ziemnym i biometanem, dotyczy wyników badań homologacyjnych. Warunki badawcze różnią się jednak istotnie od warunków 


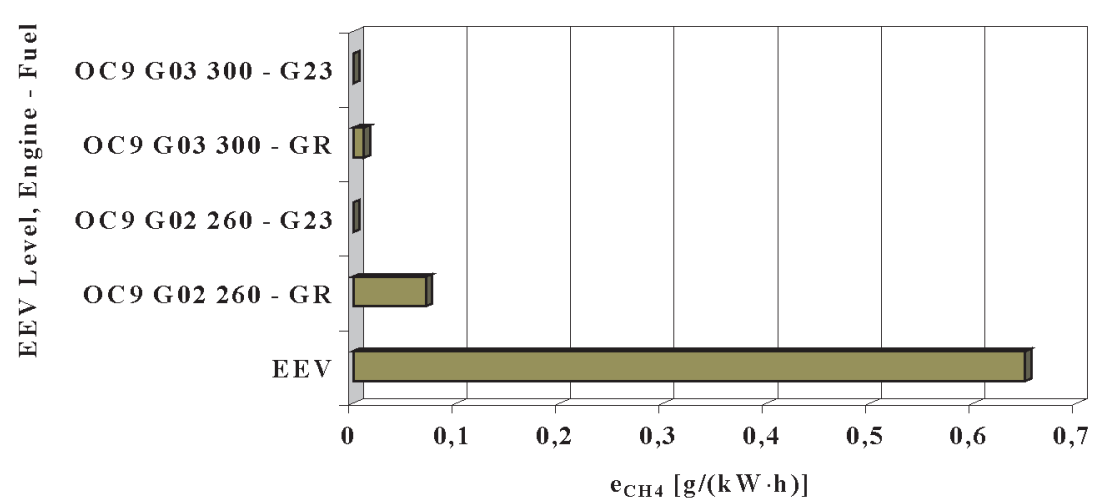

Fig. 4. Unit emission tests results of methane in the dynamic ETC test, from the OC9 G02 260 and OC9 G03 300 engines, fueled by the GR and G23 fuels, with the EEV unit emission limit

Rys. 4. Wyniki badań emisji jednostkowej metanu w teście ETC z silników OC9 G02 260 i OC9 G03 300, zasilanych paliwami GR i G23 wraz z limitem emisji jednostkowej EEV pracy silników spalinowych w rzeczywistym ruchu drogowym. Warunki pracy silników spalinowych np. w autobusach miejskich charakteryzują się znacznie mniejszymi wartościami średniej prędkości obrotowej i obciążenia oraz większym udziałem czasu pracy na biegu jałowym niż ma to miejsce $\mathrm{w}$ dynamicznych testach homologacyjnych [6]: amerykańskim HDDTT (Heavy Duty Diesel Transient Test), a szczególnie europejskim ETC (European Transient Cycle). Podobne różnice zachodzą przy rozpatrywaniu statycznych stanów pracy silników w testach homologacyjnych i w warunkach rzeczywistego użytkowania silników w autobusach miejskich. Rozważania na temat warunków pracy silnika spalinowego w autobusie miejskich są zawarte w pracy [6]. compressed natural gas or biomethane as opposed to diesel

engines [6]:

- reduction of the emission of carbon monoxide,

- reduction of the emission of hydrocarbons,

- significant reduction of the emission of cyclic hydrocarbons and their derivatives particularly polycyclic aromatic hydrocarbons (PAH),

- reduction of the emission of nitric oxides $\left(\mathrm{NO}_{\mathrm{x}}\right)$,

- reduction of the emission of particulate matter (PM).

The results of research related to combustion engines fueled with gaseous fuels are known, particularly the results of research related to the ecological consequences of the application of natural gas as engine fuel. These results are not uniform and sometimes even contradictory. This is particularly the case for the exhaust emissions that are dependent on the design properties of the engines and their operating conditions. The most information on the exhaust emissions from engines fueled with natural gas and biogas comes from the results of the homologation tests. The test conditions are quite different from the actual traffic conditions. The operating conditions of city bus engines are characterized by much lower average engine speeds and loads and a greater share of the operating time at idle as compared to the dynamic homologation tests [6]: American HDDTT (Heavy Duty Diesel Transient Test) and particularly European ETC (European Transient Cycle). Similar differences occur when analyzing the stationary engine states in the homologation tests and the actual traffic conditions of city buses. The analyses of the operating conditions of engines fitted in city buses are contained in [6].

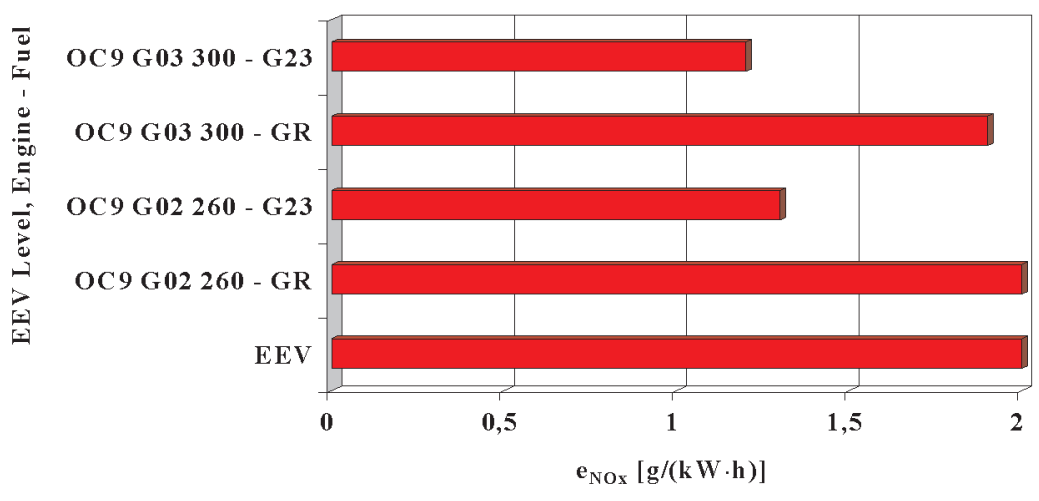

Fig. 5. Unit emission tests results of nitrogen oxides in the dynamic ETC test, from the OC9 G02 260 and OC9 G03 300 engines, fueled by the GR and G23 fuels, with the EEV unit emission limit

Rys. 5. Wyniki badań emisji jednostkowej tlenków azotu w teście ETC z silników OC9 G02 260 i OC9 G03 300, zasilanych paliwami GR i G23 wraz z limitem emisji jednostkowej EEV

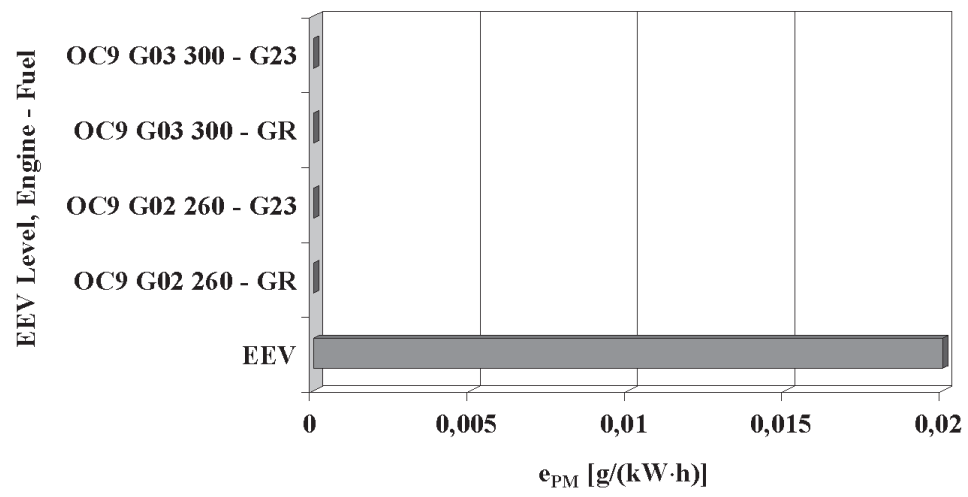

Fig. 6. Unit emission tests results of particulates in the dynamic ETC test, from the OC9 G02 260 and OC9 G03 300 engines, fueled by the GR and G23 fuels, with the EEV unit emission limit

Rys. 6. Wyniki badań emisji jednostkowej cząstek statych w teście ETC z silników OC9 G02 260 i OC9 G03 300, zasilanych paliwami GR i G23 wraz z limitem emisji jednostkowej EEV 
Figures 1 and 2 present the results of the unit emission tests in the ETC homologation dynamic test for engines fitted in city buses in the period when the Euro IV limits were applicable. The graphs present the results of tests on a traditional engine fueled with diesel oil - PD and four spark ignition engines fueled with natural gas: CNG 1-4.

The homologation tests results of engines fitted in city buses, both diesel and spark ignition (CNG) presented as an example in this subchapter, indicate how significant are the possibilities of improvement of the ecological properties in terms of exhaust emissions if $\mathrm{CNG}$ is applied.

Figures $3-6$ present the example homologation test results in the ETC tests of the engines manufactured by Scania - models: OC9 G02 260 and OC9 G03 300. These engines are used in buses in downtown Stockholm and are fueled with biomethane. The homologation tests have been performed for two fuel standards: GR and G23 [6].

Paper reviewed/Artykut recenzowany
Na rysunkach 1 i 2 przedstawiono wyniki badań emisji jednostkowej w homologacyjnym teście dynamicznym ETC dla silników autobusów miejskich w okresie obowiązywania limitów emisji jednostkowej zanieczyszczeń na poziomie Euro IV. Na wykresach przedstawiono wyniki badań silnika klasycznego o zapłonie samoczynnym zasilanego olejem napędowym - PD oraz czterech silników o zapłonie iskrowym zasilanych gazem ziemnym: CNG 1-4.

Wyniki badań homologacyjnych silników spalinowych stosowanych do napędu autobusów, zarówno o zapłonie samoczynnym, jak i o zapłonie iskrowym na gaz ziemny, przedstawione przykładowo w niniejszym podrozdziale, wskazują jak znaczące są możliwości poprawy właściwości ekologicznych silników w zakresie emisji zanieczyszczeń dzięki zastosowaniu paliwa gazowego.

Na rysunkach $3-6$ przedstawiono wyniki badań homologacyjnych w teście ETC silników produkcji koncernu Scania - modeli OC9 G02 260 i OC9 G03 300. Silniki te są zastosowane w autobusach użytkowanych w centrum Sztokholmu i są zasilane biometanem. Badania homologacyjne wykonano dla dwóch standardów paliwa: GR i G23 [6].

\section{Bibliography/Literatura}

[1] European Project Baltic Biogas Bus.

[2] GUS „Transport. Wyniki działalności w 2009 r.”, s. 78.

[3] GUS „Transport. Wyniki działalności w 2009 r.”, s. 182.

[4] GUS „Transport. Wyniki działalności w 2009 r.”, s. 179.

[5] NGVA Europe.

[6] Wojciechowski A., Chłopek Z., Gis W., Krupiński M., Menes E., Merkisz J., Waśkiewicz J., Żółtowski A.: Alternative Powertrains City Busse. 2010 International Conference on Electric Vehicles. Warsaw University of Technology, July 2010.

[7] Nylund N.O., Erkkilä K., Lappi M, Ikonen M.: Transit bus emission study: comparison of emissions from diesel and natural gas buses. Research Report PRO3/P5150/04 15.10.2004.

[8] Nylund N.O., Lawson A.: Exhaust emissions from natural gas vehicles. Issues related to engine performance, exhaust emissions and environmental impacts. IANGV Emission Report 2000.

Wojciech Gis, DEng. - Head of Environment Protection Centre in Motor Transport Institute in Warsaw.

Dr inż. Wojciech Gis - kierownik Centrum Ochrony Środowiska w Instytucie Transportu Samochodowego $w$ Warszawie.

e-mail:wojciech.gis@its.waw.pl

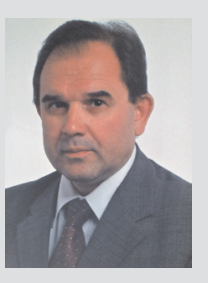

Edward Menes, PhD. - Deputy Director for Economic and Planning in Motor Transport Institute in Warsaw.

Dr Edward Menes - zastępca Dyrektora ds. Ekonomiki i Planowania w Instytucie Transportu Samochodowego w Warszawie.

e-mail:edward.menes@its.waw.pl

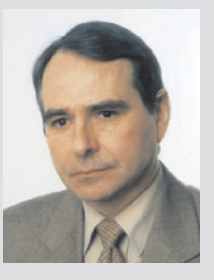

[9] Chłopek Z., Magierski M.: The ecological properties evaluation of the use natural gas engines to buses in accordance to the directive on the promotion of clean and energy-efficient road transport vehicles. VIII International Scientific Conference "Gas Engines 2010".

[10] Michałowski R.: Zasilanie CNG alternatywną dywersyfikacji paliw silnikowych, Dolnośląska Spółka Gazownicza sp. z o.o.; V Seminarium Sieci Naukowo-Gospodarczej „Energia”, Wrocław 2007.02.26.

[11] Nylund N.O.: Environmental benefits with biogas buses. Nordic Biogas Conference. Oslo, 10-12 March 2010.

[12] Podziemski T., Bałut H.: Samochody z napędem CNG znaczącym segmentem rynku gazu ziemnego? 2004.

[13] Biuletyn Informacyjny ITS nr 1/2006 za Polska Gazeta Transportowa $\mathrm{nr}$ 49/2005.

[14] Zieliński M.: Zasilanie CNG alternatywą dywersyfikacji paliw silnikowych, Dolnośląska Spółka Gazownicza sp. z o.o.; V Seminarium Sieci Naukowo-Gospodarczej „Energia”, Wrocław 2007.02.26.

[15] www.cng.auto.pl

[16] www.cng.auto.pl/pojazdy/pojazdy-autobusy/pojady-autobusycng-polska

[17] COM (2010) 186.

[18] European alternative fuel strategy in the Clean Transport Systems Initiative. JEG “Transport \& Environment”.

Jerzy Waśkiewicz, DEng. - Head of the Economic Research Department in Motor Transport Institute in Warsaw.

Dr inż. Jerzy Waśkiewicz - kierownik Zakładu Badań Ekonomicznych w Instytucie Transportu Samochodowego w Warszawie.

e-mail: jerzy.waskiewicz@its.waw.pl

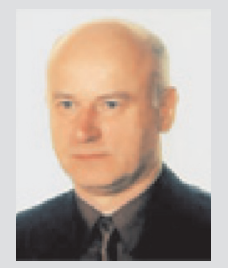

